\title{
Educatıon Policy of Audit Firms in Turkey
}

\author{
Evren Dilek Sengur \\ School of Management, Istanbul University, Turkey
}

\begin{abstract}
Enhanced transparency of audit firms provides information regarding audit firms corporate governance and quality control applications. Moreover, transparency improves audit quality. Focusing on education of partners and staff may also contribute to a culture that promotes audit quality. This paper investigates whether continuing education part of transparency reports are in accordance with the Independent Audit By-Law and whether there is a difference on transparency in 2014, 2016 and 2017. In the study, 2017 transparency reports of 88 audit firms are examined and content analysis is conducted. According to the results of the study it can be concluded that there is no significance increase in the transparency level of companies regarding their education policy since 2014. It is higly recommended that all audit firms should consider disclosing Continuing Professional Education (CPE) hours of each auditors in their transparency reports in the future.
\end{abstract}

Keywords: Transparency report, audit firms, continuous education, Turkey

DOI: $10.7176 / \mathrm{EJBM} / 11-11-13$

Publication date: April $30^{\text {th }} 2019$

\section{Introduction}

Financial scandals in the mid-2000s focused attention on the role of auditors in the capital markets and caused securities regulators to examine ways to improve audit quality. Transparency may improve audit quality. Transparency about indicators of audit quality may provide detailed information necessary to make rationale decisions for investors.

Trust in the auditing profession is a prerequisite for an audit to have value. Enhanced transparency of audit firms may increase investor confidence in financial reporting and provide additional information regarding audit firms corporate governance and quality control applications.

In order to increase transparency of audit firms, regulators in a number of jurisdictions require audit firms to issue a transparency report. In this regard, the EU Eighth Directive requires disclosures on audit firm governance from audit firms with Public Interest Entity (PIE) clients. Independent Audit By-Law in Turkey has requirements similar to those contained in Article 40 of the EU Directive.

This paper investigates whether continuing education part of transparency reports are in accordance with the Independent Audit By-Law and whether there is a difference on transparency in 2014, 2016 and 2017. The sample of the study consists of 88 audit firms that audited public interest entities (PIEs) in 2016 in Turkey. The rest of this paper is organized as follows. Section II summarizes academic literature about transparency reporting in Turkey, Section III explains international legislations regarding transparency of audit firms, Section IV outlines the research design and provide descriptive statistics, and Section V concludes the study.

\section{Literature Review}

Demirkan (2016) reviewed and summarized the content of transparency reports of 73 audit firms that performed an audit of a public interest entity in 2014 in Turkey. Gurol \& Tuysuzoglu (2015) also analysis transparency reports of audit firms that performed an audit of a public interest entity in 2014. In their study they provide recommendations and comments on transparency reports in order to increase the sufficiency and quality of information provided.

Erdogan \& Solak (2016) examines transparency reports of 2013. According to the results of the study, Turkish auditing sector is a emerging sector, clustered in large cities such as Istanbul, dominated by the big four auditing firms. Moreover, large firms get audit service largely from the big four audit firms. 
In their study Gürol \& Tuysuzoglu (2017) examines regulations on transparency reports and reviews the transparency reports of four major audit firms (Deloitte, Ernst \& Young, KPMG and PricewaterhouseCoopers) in the US, Australia, UK, Canada and Turkey to provide examples of practices that will be useful in meeting the needs of users.

Tanc \& Gumrah (2016) review content of 69 transparency reports in 2014, within the scope of continuing education policy issues. According to the research results, it has been determined that independent auditing firms either didn't fully understand the importance of continuous vocational training or they cannot clearly share the relevant practices with the interest groups. Kavut (2017) replicates the study in 2017, examines continuing education policy part of 75 transparency reports of 2016.

\section{Transparency of Audit Firms}

Transparency reporting can foster corporate governance implementation within audit firms and may encourage audit firms to sharpen their focus on audit quality, which would also be of benefit to investors and other stakeholders. In addition, audit firm transparency reporting can aid management for selecting an auditor by comparing provided information on a firm's audit quality. Additionally, transparent reporting would provide clients and potential investors with comparable information on all audit firms and might thus, revive competition in the audit market as well as reduce opportunistic behavior of auditors (Pott, Mock \& Watrin; 2008). IOSCO believes that an audit firm transparency report could be considered of high quality if the information in the report includes; the audit firm's legal and governance structure; the audit firm's measures to foster audit quality; the audit firm's internal indicators of audit quality; and the audit firm's indicators of audit quality as generated by the work of external bodies. (IOSCO; 2015)

The 8th Company Law Directive on statutory audits was adopted by the European Union (EU) in 2006. The Eighth EU Directive, requires statutory auditors of Public Interest Entities (PIEs) to publish, annual transparency reports as of June 2008. According to the Directive, information relating to legal structure and ownership, governance structure, internal quality control system, quality assurance, education and independence practices, and partner remuneration should be provided in transparency reports.

In Turkey Independent Audit By-Law was published on December 26, 2012 and regulates the principles and procedures related with independent audit, independent auditors and independent audit firms. Independent Audit By-Law requires transparency reports to be prepared by those Turkish audit firms which have provided audit audit services to Public Interest Entities (PIEs) in the last reporting year. In accordance with the Article 36 of By-Law, transparency reports should include the following:

a) A description of the legal structure and ownership;

b) A description of key management of the audit firm

c) Where the audit firm belongs to a network, a description of the network and the legal and structural arrangement in the network;

d) A description of the related audit firms

e) A description of the organisation structure of the audit firm

f) An indication of when the last quality assurance review took place;

g) A list of public interest entities for which the audit firm has carried out statutory audits during the preceding financial year

h) A statement on the policy followed by the audit firm concerning the continuing education of statutory auditors

i) A statement concerning the audit firm's independence practices, which also confirms that an internal review of independence compliance has been conducted;

j) Distribution of revenue based on service provided as auditing, and non-auditing services.

k) Information concerning the basis for the partners' remuneration.

1) A description of the internal quality control system of the audit firm and a statement by the administrative or management body on the effectiveness of its functioning;

m) Other information required by Public Oversight Accounting and Auditing Standards Authority (KGK). 
In Turkey, Independent Audit By-Law obliges auditing firms which carry out audits of public interest companies to prepare transparency reports and to publish them on their websites within three months.

\section{Analysis of Transparency of Audit Firms In Turkey}

One of the key drivers of quality is ensuring the assignment of professionals with the skills and experience appropriate to the entity subject to audit. This requires a focus on professional training and education. Auditing standards are continuously evolving and amended ISAs and IFRSs are issued every year. Audit quality relies on audit professionals continually updating their knowledge and skills. Auditors should enhance their knowledge, skills, and other competencies through continuing professional development.

According to Article 25 of Independent Audit By-Law auditors are educated on a continous basis for the purpose of keeping their theoretical knowledge and professional skills at a sufficient level, complying with professional ethics, following up changes in the professional field, and ensuring their professional development.

According to Continuous Education for Auditors By-Law, auditors must attain and report a minimum of 120 Continuing Professional Education (CPE) hours for a three-year reporting period. It is required for auditors to maintain their professional competence and provide quality professional services. The By-Law is published by Public Oversight Accounting and Auditing Standards Authority (KGK) to provide a framework for the development, presentation, measurement and reporting of CPE programs.

This study replicates two previous studies conducted by Tanc \& Gumrah in 2016 and Kavut in 2017. The aim of the study is to compare the results of three studies and reach a conclusion regarding improvement in transparency of firms. The study investigates whether there is a difference in education part of transparency reports between the years of 2014, 2016 and 2017. The analysis comprises the examination of the countinous professional education parts of audit transparency reports.

Table 1: Number of Pages

\begin{tabular}{|l|c|c|c|}
\hline & \% & \% & \% \\
& $\mathbf{( 2 0 1 7 )}$ & $\mathbf{( 2 0 1 6 )}$ & $\mathbf{( 2 0 1 4 )}$ \\
\hline 1 page & $\% 80$ & $\% 80$ & $\% 73$ \\
\hline 2 pages & $\% 11$ & $\% 12$ & $\% 20$ \\
\hline 3 pages & $\% 3$ & - & - \\
\hline More than 3 pages & $\% 6$ & $\% 8$ & $\% 7$ \\
\hline
\end{tabular}

Table 1 presents the number of pages in a transparency report covering education policy and applications of audit firms. As it is shown in the table, most of the audit firms explanation regarding education contains only one page in a transparency report. 
Table 2: Content of Transparency Reports

\begin{tabular}{|l|c|c|c|}
\hline & $\mathbf{\%}$ & $\mathbf{\%}$ & $\mathbf{\%}$ \\
& $\mathbf{( 2 0 1 7 )}$ & $\mathbf{( 2 0 1 6 )}$ & $\mathbf{( 2 0 1 4 )}$ \\
\hline Training and education policy & $\% 92$ & $\% 77$ & $\% 78$ \\
\hline Continous or routine education & $\% 90$ & $\% 88$ & $\% 52$ \\
\hline Special purpose or non-routine education & $\% 74$ & $\% 69$ & $\% 93$ \\
\hline Duration of education & $\% 77$ & $\% 73$ & $\% 92$ \\
\hline Subjects of education & $\% 80$ & $\% 93$ & $\% 81$ \\
\hline Information about educators & $\% 23$ & $\% 24$ & $\% 14$ \\
\hline Attendance of university training programs & $\% 5$ & $\% 3$ & $\% 1$ \\
\hline Attedance of professional chamber's training programs & $\% 7$ & $\% 8$ & $\% 22$ \\
\hline $\begin{array}{l}\text { Attendance of academic meetings (conference, symposium } \\
\text { etc.) }\end{array}$ & $\% 10$ & $\% 16$ & $\% 61$ \\
\hline
\end{tabular}

Table 2 summarises the results of the study and provides comparison with previous studies. $\% 92$ of audit firms explicitly state their training and education policy in their transparency reports. Legislation regarding accounting and auditing are amended frequently. In order to update their theorical and professional knowledge, auditors have to attend trainings, educations and conferences regularly. $\% 90$ percent of firms express that auditors attend trainings as a part of continous or routine education. On the other hand, sometimes auditors may need to gain information concerning special topics such as communication, team work or leadership. $\% 74$ of audit firms claim that auditors take special purpose or non-routine education in 2016. \%77 of audit firms declare duration of education taken during 2016 in terms of hour or date. Average education time is 187 hours in 2016. Additionally, $\% 80$ of firms provide subjects of education. Moreover, only $\% 23$ of firms express information about educators. Auditors may improve their professional knowledge by gaining information in different types of activities such as university training programs, professional chamber's training programs or academic meetings. The percentage of audit firms that explicitly states that auditors attend university training programs, professional chamber's training programs or academic meetings in 2016 are $\% 5, \% 7$ and $\% 10$, respectively.

\section{Conclusion}

This paper assesses transparency of audit firms in the area of continuous education. In the study, professional continuous education part of 88 transparency reports are examined. Results were compared with previous studies in order to portray the development of transparency in this area. According to the result of the study it can be cocluded that there is no significance increase in the transparency level of companies regarding their education policy since 2014. It is higly recommended that all audit firms should consider disclosing Continuing Professional Education (CPE) hours of each auditors in their transparency reports in the future.

The study contributes to the corporate governance and disclosure literature in the following ways. First, the study provides evidence on the extent of education part of transparency report disclosures in compliance with Independent Audit By-Law. Second, it expands the studies of Tanc \& Gumrah (2016) and Kavut (2017) by comparing the results of the studies. Such comparison reveals the degree of development in transparency resporting over the years. 


\section{References}

Demirkan A. (2016) Transparency reports of audit firms, Muhasebe ve Denetim Dünyast, 1 (1), 43-54.

Erdogan S. \& Solak B. (2016). An empirical study of transparency reports and the auditing sector in Turkey, Çankırl Karatekin University Journal of The Faculty of Economics and Administrative Sciences, Vol.6, No.2, 175-195.

Gürol B. \& Tuysuzoglu T. (2016). A review and evaluatioin on transparency reports of Turkish audit firms, Muhasebe ve Denetime Bakış, (47), 131-148.

Gürol B. \& Tuysuzoglu T. (2017). Best practices in transparency reporting and a comparative study on country differences, Muhasebe Bilim Dünyası Dergisi, 19 (1), 189-206.

Kavut L. (2017) Bağımsız denetimde kalite: şeffaflık raporları üzerinde bir inceleme, Seçmeler 2018, 77-92.

Pott, C., Mock, T.J. and Watrin, C. (2008), “The effect of a transparency report on auditor independence: practitioners' self-assessment”, Review of Managerial Science, Vol. 2 No. 2, pp. 111-127.

Public Oversight Accounting and Auditing Standards Authority (KGK), Independent Audit By-Law (2012), http://www.kgk.gov.tr/Portalv2Uploads/files/Duyurular/v2/Mevzuat/BDY/Guncel\%20BDY.pdf

Public Oversight Accounting and Auditing Standards Authority (KGK), Continuous Education for Auditors ByLaw

http://www.kgk.gov.tr/ContentAssingmentDetail/1382/Bag\% $\% \mathrm{CC} \% 86 \% \mathrm{C} 4 \% \mathrm{~B} 1 \mathrm{~ms} \% \mathrm{C} 4 \% \mathrm{~B} 1 \mathrm{z}-$ Denetc $\%$ CC $\%$ A7iler-I\%CC $\% 87 \mathrm{c} \% \mathrm{CC} \% \mathrm{~A} 7 \mathrm{in}-\mathrm{Su} \% \mathrm{CC} \% 88$ rekli-Eg\%CC\%86itim-Teblig\%CC $\% 86 \mathrm{i}-$ Resmi-Gazete $\%$ E2\%80\%99de-Yay $\% \mathrm{C} 4 \% \mathrm{~B} 1 \mathrm{mlanm} \% \mathrm{C} 4 \% \mathrm{~B} 1 \mathrm{~s} \% \mathrm{CC} \% \mathrm{~A} 7 \mathrm{t} \% \mathrm{C} 4 \% \mathrm{~B} 1 \mathrm{r}$.

Tanc A. \& Gumrah A. (2016). The analysis of audit firms' continuing professional education policies within the framework of transparency reports, Muhasebe Bilim Dünyası Dergisi, 18, 419-438. 